Georgios D. PANAGOPOULOS*

\title{
THE THEORY OF EIINOIA \\ IN ST. BASIL OF CAESAREA \\ AND EUNOMIUS OF CYZICUS: \\ PHILOSOPHICAL AND THEOLOGICAL BACKGROUND
}

The aim of this presentation is to shed light on the way in which Saint Basil bishop of Caesarea at the second half of forth century, prompted by the positions of his opponent, the neoarian bishop of Cyzicus Eunomius, integrated in their theological thought the philosophical teaching about the formation of concepts in human mind ( $\dot{\varepsilon} \pi^{\prime} v_{v}(\alpha)$. As known, Eunomius proposed a double methodological process (the two roads marked out for us for discovering what we seek) in order to discover the ontological true of God; it was essentially a kind of metaphysics of essences, that is an essentialist conception of a hierarchy of beings established with the aim at proving the ontological dissimilarity existing supposedly between God the Father and His Son. One pillar of his thought was the claim that certain concepts provide us with access to the essence of the Supreme Being.

In what follows I'll focus my attention on the manner in which St. Basil turned a piece of Hellenistic epistemology to advantage in an attempt to set forth an empiricist theological epistemology by means of which he refuted the Eunomian metaphysics of essences ${ }^{1}$.

\footnotetext{
${ }^{*}$ Dr Georgios D. Panagopoulos - Assistant Professor of Dogmatics of the Orthodox Church of University Ecclesiastical Academy of Vella of Ioannina, Greece; e-mail: panagopoulosg@yahoo.gr.

${ }^{1}$ Let aside the extent presentation by Th.A. Kopecek (A History of Neo-Arianism, Patristic Monograph Series of the North American Patristic Society 8, vol. 2, Cambridge MA 1979), the neoarian theology of Eunomius has been thoroughly investigated only recently by R.P. Vaggione, Eunomius of Cyzicus and the Nicene Revolution, Oxford 2000. Nevertheless, one could find a more or less accurately elaborated survey of eunomian theology in general works on history of Christian doctrine as well as in various articles: L. Abramowski, Eunomios RACh VI 936-947; J.N.D. Kelly, Early Christian Doctrines, New York 1960, 249; M. Simonetti, La crisi ariana La crisi ariana nel IV secolo, Roma 1975, 462-468; R.P.C. Hanson, The Search for the Christian Doctrine of God. The Arian Controversy 318-381, Grand Rapids MI 2007, 598-636; B. Sesboüé, Saint Basile et la Trinité. Un acte théologique au IV siècle, Paris 1998, 19-54; and more recently L. Ayres, Nicaea and his Legacy. An Approach to Fourth-Century Trinitarian Theology, Oxford 2006, 146-149 (It is also to mention the $\mathrm{PhD}$ thesis of Th. Dams, La controverse eunomiéenne, Thèse polycopiée de la Faculté de Théologie de l'Institut Catholique de Paris 1952, to which, unfortunately, I didn't have any access).
} 
1. Basil's doctrine of $\dot{\varepsilon} \pi \dot{i} v o t \alpha$. As a starting point is to be taken the crucial passage of Basil's Contra Eunomium I 5, where the bishop of Caesarea ex-

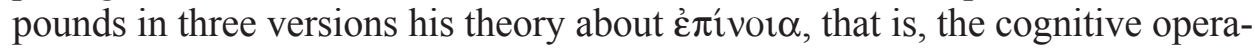
tion by which notions or concepts about things of the extramental reality are shaped in human mind. Basil lays as fundament of human knowledge the data of experience conveyed to us by our senses and exposes his view about the formation of concepts in human mind as a two steps proceeding according to which we pass from a primary simple perception impressed in the mind through sensation in a more accurately articulated concept by mental operation.

It is worth mentioning that Basil's doctrine of zं $\pi^{\prime}$ vor $\alpha$ had not yet been thoroughly investigated as far as its philosophical background is concerned. Antonio Orbe, earlier enough, had spoken of the stoic character of the theory by pointing out the importance St. Basil ascribed to the data of experience in the process of concept's shaping ${ }^{2}$. Thomas A. Kopecek, on his side, was prone to recognize the epicurean background of Basil's doctrine ${ }^{3}$, a suggestion that it is in no way at odds with that of Orbe given the likeness existing between stoic and epicurean $\dot{\varepsilon} \pi \dot{i} v o t \alpha$ theory, as the related evidence from Diogenes Laertius allows to suggest ${ }^{4}$. More recently Karl-Heinz Uthemen, based upon Eunomius' critic against Basil as reported by Gregory of Nyssa, talked of stoic origin ${ }^{5}$, while Maria S. Troiano incorrectly suggested that Basil's doctrine doesn't have any historical precedent ${ }^{6}$.

Let's now investigate more thoroughly what the Cappadocian bishop was thinking about $\varepsilon^{\prime} \tau^{\prime} v o r \alpha$. In the first version of his definition St. Basil illustrates the $\varepsilon^{\prime} \tau^{\prime}$ vor $\alpha$ - as he says in accordance to the current usage - as an operation of human mind (vov̂s):

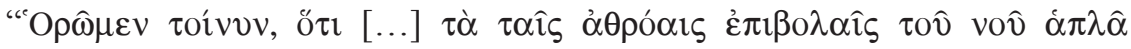

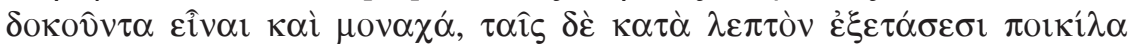

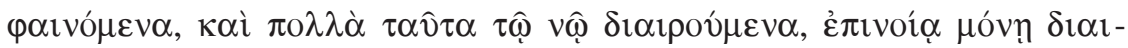
$\rho \varepsilon \tau \grave{\alpha} \lambda \varepsilon \dot{\varepsilon} \gamma \varepsilon \tau \alpha \iota "$ "

${ }^{2}$ Cf. A. Orbe, La Epinoia. Algunos preliminares historicos de la distinction $\kappa \alpha \tau$ '̇ं $\pi^{\prime} v o t \alpha v$, Romae 1955, 41: "La Epinoia es como la flor y nata del pensiamento espontaneo provocado en el almapor los sentidos".

${ }^{3}$ Cf. Kopecek, A History of Neo-Arianism, vol. 2, p. 461.

${ }^{4}$ Cf. Diogenes Laertius, Vitae philosophorum VII 53 = SVF II 87; ibidem X 32; cf. also A. Long - D. Sedley, The Hellenistic Philosophers, vol. 2: Greek and Latin texts with notes and bibliography, Cambridge 1987, 240.

${ }^{5}$ Cf. K.-H. Uthemann, Die Sprache der Theologie nach Eunomius von Cyzicus, ZKG 104 (1993) 163.

${ }^{6}$ Cf. M.S. Troiano, I Cappadoci e la questione dell'origine dei nomi nella polemica contro Eunomio, VetCh 17 (1980) 314.

${ }^{7}$ Basilius Caesariensis, Adversus Eunomium I 5, ed. B. Sesboüé-G.M. de Durand -L. Doutreleau, SCh 299, Paris 1982, 184, 21-25. 
It is about an activity of ratio discursiva, which after having focused to

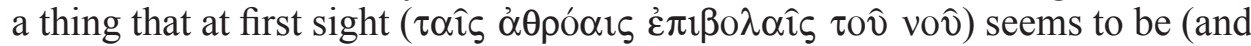
from a point of view actually is) simple and single, then proceeds, based on

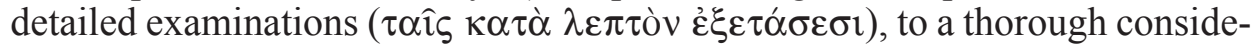
ration with the result that this same thing comes to appear as varied and many, because it has been mentally divided ( $\delta \iota \alpha \iota \rho o v e \varepsilon v \alpha)$. In such a case one talks of things that are dividable into different aspects according only to $\varepsilon \pi^{\prime}{ }^{\prime} v o r \alpha$,

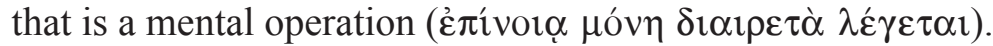

To elucidate the issue Basil holds up as an example the case of body. Although the first apprehension conveys to us the impression that it is a simple thing, then comes the more articulated reasoning which presents it as a complex one by decomposing it through the mental operation of epinoia into the elements of which the body is made up, that is, colour, figure, hardness, magnitude etc. ${ }^{8}$ Needless to say that St. Basil doesn't distinguish here between the so-called primary and secondary qualities of a thing, as did earlier Democritus or later, actually more accurately, John Lock'

The second version of the definition advanced by St. Basil presents the epinoia as the cognitive operation which takes as starting point the perception

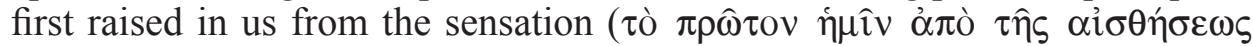

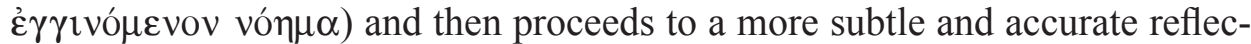

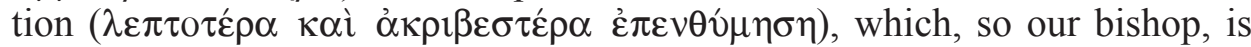
called ह̇ंívor $\alpha$. As illustrating example Basil uses the case of grain:

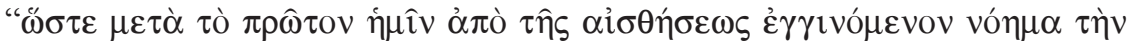

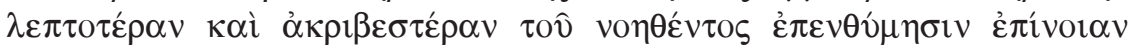

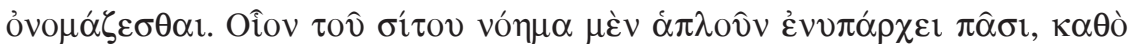

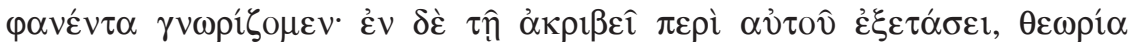

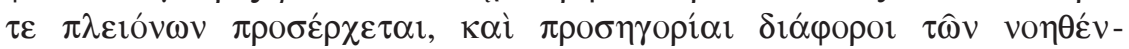
$\tau \omega \nu \sigma \eta \mu \alpha \nu \tau i \kappa \alpha i{ }^{\prime \prime 10}$.

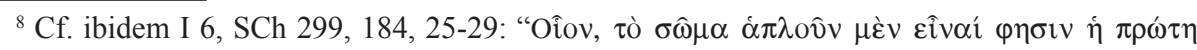

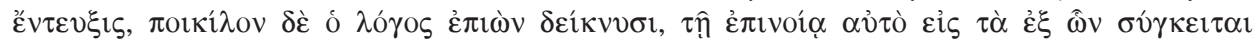

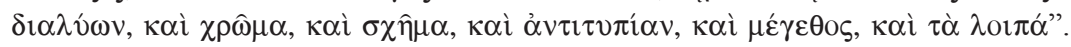

${ }^{9}$ As already known, Lock defined the primary qualities as thing's powers capable of producing in us an idea (e.g. white, cold, round e.c.). Primary qualities are inseparable of the thing, whatever change it undergoes. On the other hand, he considered as "secondary" qualities which are nothing in the objects themselves but powers to produce various sensations in us, such as colours, sounds, tastes and odors, cf. J. Lock, An Essay Concerning Human Understanding II 8, 9, ed. J. Manis, Pennsylvania State University, Hazleton (PA) 1999, 117; cf. also F. Copleston, A History of Philosophy. British Philosophy: Hobbes to Hume, London 2003, 86-88; in regard to Democritus cf. Plutarchus, Adversus Colotem 1110E; Diogenes Laertius, Vitae philosophorum IX 45; also J. Barnes (The Presocratic Philosophers, London - New York 2006, 371), who advanced doubts about the current interpretation of the aforementioned quotations.

${ }^{10}$ Basilius Caesariensis, Adversus Eunomium I 6, SCh 299, 186, 41-47. 
Putting aside, for the purpose of my presentation, the third account about epinoia, where, St. Basil summarizes his doctrine by combining the two aforementioned versions, I'll concentrate my attention to the second one and particularly to the example of grain. It is exactly this which should be especially taken into consideration, since both its meaning and its terms recall crucial elements of the Hellenistic epistemology. Basil says that the meaning of grain

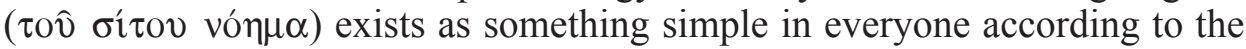
knowledge we acquire of it by virtue of his appearance to us through sensa-

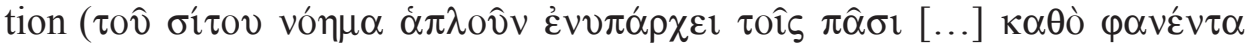
$\left.\gamma \nu \omega \rho^{\prime} \zeta \mathrm{o} \mu \varepsilon v\right)$. But as a result of a more accurate inquiry arises a consideration of many aspects of the thing as well as the need to utilize various names ( $\pi \rho \circ \sigma \eta \gamma о \rho i \alpha l)$ signifying them.

Basil explains what he says by referring to the fact that we call the same grain fruit when we have to do with the product of the previous crop; we also call it seed as start of the next one; last but not least we call it food as something adequate for our bodily development. Here it is not so much of importance the fact that the example of grain had been several times used by philosopher of Hellenistic period in similar contexts ${ }^{11}$; more significant for our purpose is the striking resemblance of crucial terms appeared in our passage with those used by the main philosophers of Stoa, such as Chrysipp; I mean here terms such as

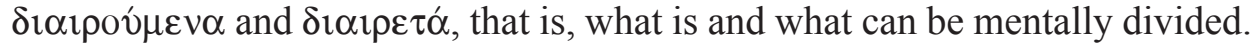

Moreover, in my PhD Thesis, published in Athens eight years ago ${ }^{12}$, I've tried to establish the view that Basil's description of the first apprehension of a thing as a simple notion shaped on all human beings according to the sense data is to be interpreted under the light of the stoic prolepsis, that is, the preconception of a thing which is shaped in humans naturally and without special

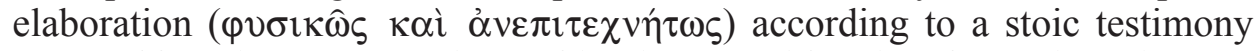
reported by Diogenes Laertius. Taking into consideration that stoic $\pi \rho o ́ \lambda \eta \psi 1 \varsigma$ as well as the result of first apprehension according to Basil's second account of '̇ं ívor $\alpha$ are the product of reason's natural activity on sense data accumulated by repeated experience ${ }^{13}$, taking further into consideration the fact that St. Basil adheres to the stoic-aristotelian view, that human soul is like a wax upon which sense perceptions get impressed, then one can easily recognize the empiricist aspect of Basil's epistemology.

${ }^{11}$ Cf. evidences from Alexander of Aphrodisias, Amonios, son of Ermias etc. in: G.A. Dimi-

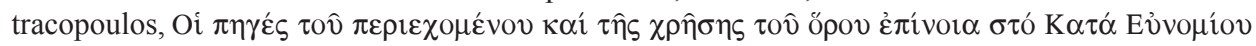

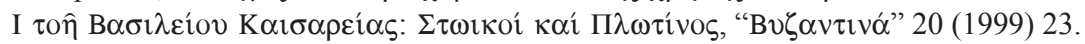

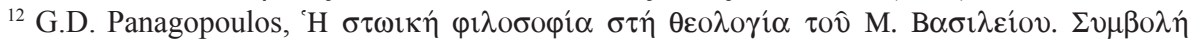

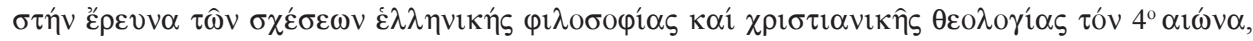
AӨñva 2009, passim.

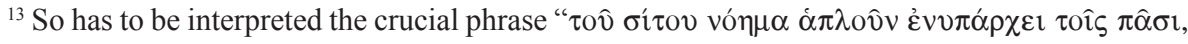

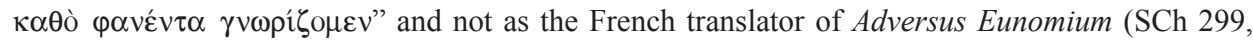
187) in the Sources Chrétiennes series suggests. 
Moreover, as one can see, in this second definition Basil conceives ż $\pi^{\prime}$ vor $\alpha$ as a cognitive process by means of which starting from the notion of a thing as it appears through sensation to us in the present, one comes to figure out properties or aspects of it which characterize it either in the past or in the future. As I have also proved elsewhere, St. Basil turned to his own advantage here the stoic theory of concept's shaping in its relation to different periods of time. Basil's position that starting from a present thing human mind can be led to temporarily unrevealed aspects of it by projecting himself into the future or into the past is to be considered in comparison with stoic passages from Chalcidius' Commentarius in Timaeum or Cicero's De officiis which admittedly conveys stoic ideas ${ }^{14}$.

True, Basil elaborates his é $\pi^{\prime}$ vor $\alpha$ model on the basis of what occurs in the realm of our sense experience. Concepts or notions shaped on the ground of sense data by reason's activity enable as to think and speak about our world using various names signifying properties or aspects and picking through them out individual things. But although he several times lays stress on the unbridgeable ontological difference existing between the uncreated nature, that is God, and the created one, he feels nonetheless free to apply the doctrine of غ̇ंivor $\alpha$ in theology. He is obviously concerned to provide a solid base to talk about God, especially about the salvific revelation of God in the Person of the Incarnate God the Son without yielding to any kind of metaphysic of essences. After all, theological names reflect the charismatic experience of the members of Christ's body without exhausting it in notional entities, terms and names; hence they must be regarded as a pastoral guide in the process of spiritual growth of believers in Christ.

2. Epistemology of Basil and Eunomius in a comparative survey. Let's now trace an outline of the theological epistemology of the two theologians in a comparative survey. On the one side Eunomius disregarded human concepts and names about God as pure flatus vocis (an ultranominalistic view) by pointing to the various products of human reason's activity, such as the Centaurs, which obviously are devoid of any true value so far as they don't correspond to any extramental reality. The examples used here by Eunomius recall admittedly the stoic catalogue of the so called meaningless names $(\not \circ \sigma \eta \mu \alpha)^{15}$. But, nontheless, Eunomius goes a step further. The neoarian bishop opted for a theory according to which there are certain concepts to which we must ascribe a special

${ }^{14}$ Cf. Chalcidius, Commentarius in Timaeum 220 = SVF II 879 (cf. Long - Sedley, The Hellenistic Philosophers, vol. 2, p. 313); Cicero, De officiis I 4: "homo autem, quod rationis est particeps, per quam consequentia cernit, causas rerum videt earumque praegressus et quasi antecessiones non ignorat, similitudines comparat rebusque praesentibus adiungit atque annectit futuras, facile totius vitae cursum videt ad eamque degendam praeparat res necessarias"; Plato, Theaetetus

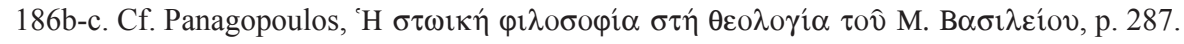

${ }^{15}$ Cf. Diogenes Laertius, Vitae philosophorum VII 57; Sextus Empiricus, Adversus mathemati$\cos$ VIII 133. 
epistemological status in so far as they have been somehow impressed by God to human souls. The eunomian theory concerning natural notions ( $\varphi v \sigma \iota \kappa \alpha i$ Évvolal), whose roots are to be looked for in the middle platonic interpretation

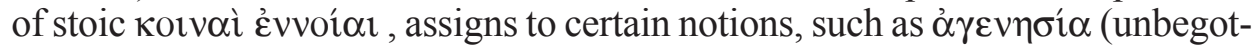
teness) as well as to its synonyms, the function to reveal God's essence in virtue of being allegedly innate to human souls. In this way Eunomius aimed at proving the full ontological dissimilarity between God the Father, the first and only thru God in his onto-theological system, and the second divine being, that is the Son, given the fact that the supposedly revealing the divine essence concept of $\dot{\alpha} \gamma \varepsilon v \eta \sigma i \alpha$ (unbegotteness) has been always associated only with the Father.

In contrast to Eunomius, St. Basil is arguing for the epistemological value of $\dot{\varepsilon} \pi \dot{i} v o r \alpha$ also in theology by according to human concepts and names shaped on the basis of empirical data a real reference to God and at the same time ruling out any possibility of knowing or comprehending God's being per $s e^{16}$. Our inquiry prompts to suggest that both theologians are most probably acquainted with the same philosophical material concerning human mind's concepts; nevertheless each of them evaluate differently its epistemological status in order to provide support to different theological preoccupations. Eunomius' rationalistic doctrine concerning human knowledge about God gave Saint Basil the opportunity to advance an empiricist epistemological view that on one side makes possible a talk about God based on sense data and on the other side keeps fully intact the absolute transcendence of God's essence ${ }^{17}$.

As a matter of fact in several passages of his writings, and especially in those addressed against the neoariansim, Basil lays full stress to the fact that humans have the experience of God's existence on account of His salvific activities or energies towards the world; but it doesn't mean that they can attain any kind of knowledge of the divine essence. In his Epistula 234, written more than a decade after Adversus Eunomium, St. Basil seeks to emphasize this by maintaining that

${ }^{16}$ Cf. Sesboüé, Saint Basile et la Trinité, p. 83: "Là où Eunome parlait de notion naturel-

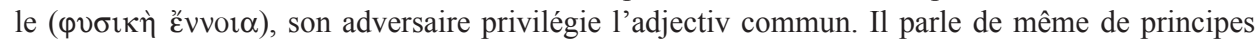

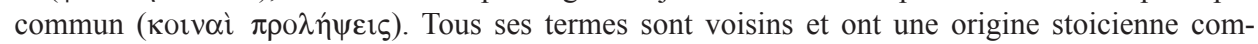
mune. Mais ils fonctionnent chez les deux hommes a l'intérieur de visées profondement différentes. Pour Eunome il s'agit d'une notion naturelle et innée dont l'origine est en Dieu lui-même; pour Basile, il s'agit de ce qui est commun à tous les hommes et appartient à la cohérence d'un usage". Notwithstanding, I'm not ready to agree with Sesboüé's view that in Basil's thought the divine Logos comes to fertilize our rational knowledge of the world; for, to my opinion, it is inappropriate to read into the texts of an author of $4^{\text {th }}$ century the kind of relation between natural and revealed knowledge elaborated in much posterior period in the Christian west.

${ }^{17}$ It should be noted at this point that Basil was not the first who applied the $\dot{\varepsilon} \pi$ ivor $\alpha$ theory in theological matters. He was surely fully aware of the fact that already Origenes had used it in his christology: Origenes, Commentarii in Johannem 1, PG 14, 60-84. Cf. M. Harl, Origène et la fonction révélatrice du Verbe incarné, Patristica Sorbonensia 2, Paris 1958, 175 and 234-236; J. RiusCamps, El Dinamismo trinitario en la divinization de los seres racionales segun Origenes, OCA 188, Roma 1970, 120-161; H. Crouzel, Origen et le probléme de la "connaissance mystique", Paris 1961, 390-391 and 470-471; J.W. Trigg, Origen, London - New York 2002, 26. 
"we know God from His energies; nevertheless we don't profess that we approach His essence; for, His energies descend to us, while his essence remains unapproachable"18.

So Basil feels himself fully justified to reject the essentialist theological epistemology of his opponent:

"we ascend to God through His energies and we think of the creator's existence from the creatures and therefore we realize His goodness and wisdom"19.

Of course, this is no to say that in this way it is granted to us any cognitive access to the divine essence. For, so St. Basil, it is ridicules to identify the creative power with the essence, the divine providence with the essence and, so to speak, to identify every energy with the essence ${ }^{20}$.

Hence the theory of $\dot{\varepsilon} \pi i$ vor $\alpha$, which the Cappadocian Father articulated by drawing, as he declares, both on Bible's teaching and the common usage (actually on stoic-epicurian accounts), enabled him to interpret the church's teaching without metaphysical connotations. In order to achieve this he put forward a concept of theological reasoning and teaching that do justice both to the empirical background of any kind of knowledge and the mind's activity without there being the need to postulate an intellectus agens in order to attain true knowledge by abstracting the metaphysical identity of things, that is, the species intelligibiles. One could therefore suggest that at this point St. Basil reminds us of how J. Lock insisted on the empiricist background of our knowledge by rejecting the theory of "innates ideas"; this means further that St. Basil allows us to distinguish his attitude from that of theologian and philosophers belonging to the platonic tradition of the medieval period ${ }^{21}$. On the other side, as one can conclude from Basil's

${ }^{18}$ Basilius, Epistula 234, 1, ed. Y. Courtonne: Saint Basile, Lettres, III, Paris 1966, 42: “"H $\mu \varepsilon \hat{\iota} \varsigma$

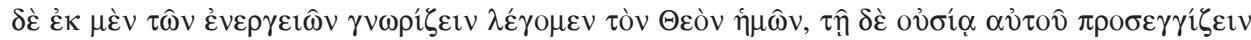

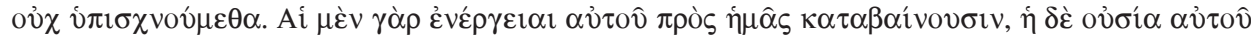

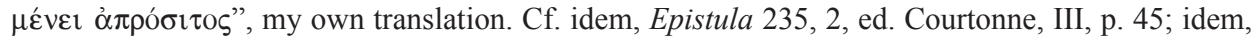
Adversus Eunomium I 14, SCh 299, 220; idem, De Spiritu Sancto IX 22, ed. B. Pruche, SCh 17b, Paris 2002, 234-236; idem, Homilia in sanctum martyrem Mamantem 4, PG 31, 597. See the related statement of V.H. Drecoll, Die Entwicklung der Trinitätslehre des Basilius von Cäsarea. Sein Weg vom Homöusianer zum Neonizäner, Göttingen 1996, 287: „Als Ergebnis dieser Argumentation hält

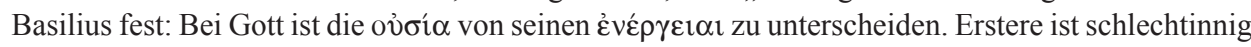

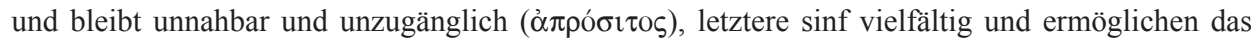

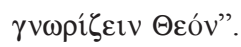

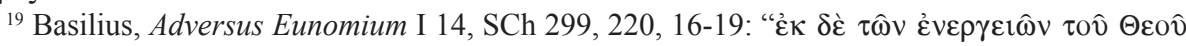

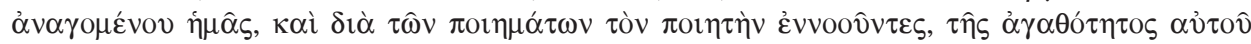

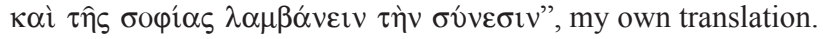

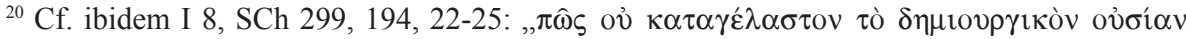

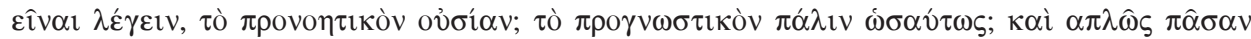

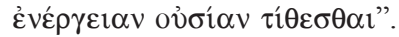

${ }^{21}$ I am referring here especially to the illuminatio doctrine, which is a Christian version of the platonic innatism. Cf. Augustinus, De magistro 12, 40. See J. Hirschberger (Geschichte der Philosophie, vol. 1: Altertum und Mittelalter, Freiburg - Basel - Wien 1991, 351) who considers it as a "platoni- 
first account of É $\pi^{\prime}$ vor $\alpha$, the bishop of Caesarea doesn't seem to accept the passiveness of human mind in the process of shaping concepts to the extent that the English Philosopher did it especially regarding to the so called "simple ideas"22.

In any case it is worth mentioning that Eunomius in his reply Apologia Apologiae accused St. Basil of having denied the divine providence on account of his philosophical concept of $\dot{\varepsilon} \pi$ ivora. Eunomius was fully aware of the fact that also his own theory of theological knowledge was of philosophical origin. The main problem for him was that St. Basil's cognitive and linguistic theory discouraged any attempt to reconstruct the order of world by means of a priori reasoning which, as a matter of fact, was the key point of Eunomian onto-theological metaphysic of essences. It is tempting to suggest that it was on the one side Eunomius' '̇ $\pi$ ívor $\alpha$ description and on the other his insistence on the ontological function of certain names-concepts that triggered St. Basil to integrate in his theological epistemology the empiricist aspect of the Hellenistic é $\pi^{i}{ }^{\prime} v o t \alpha$ theory. In doing so Basil presents a splendid model of creative use of philosophical material in order to consolidate the Christian message against the attacks of heretics who first utilized philosophy in a manner which contaminated the biblical testimony. It was not actually a verification of the medieval concept of the philosophia as ancilla theologiae; it was rather an application for pastoral reasons of the Pauline saying: "We demolish arguments and every pretension that sets itself up against the knowledge of God, and we take captive every thought to make it obedient to Christ" (2Cor 10:5).

\section{(Summary)}

In the paper our attention is focused on the way in which both Saint Basil of Caesarea and his opponent, the anomoian Eunomius of Cyzicus, integrate in their theological thought the philosophical teaching about the formation of concepts ( $\dot{\varepsilon} \pi^{i} \operatorname{lot}_{\alpha}$ ) in human mind and their relation to the external objects. Our inquiry will provide the evidence that the two theologians are acquainted with the same philosophical material concerning human mind's concepts; nevertheless each of them opted to use a different element from the related philosophical traditions in

sierende Art des Denkens"; also J. Marenbon, Medieval Philosophy. An historical and philosophical introduction, London - New York 2007, 225-226; R. Pasnau, Human Nature, in: A.S. McGrade, A Cambridge Companion to Medieval Philosophy, Cambridge 2003, 219: "divine illumination held a central place in medieval epistemology until the thirteenth century, when it was gradually displaced by Aristotelian empiricism"; and last but not least N. Abbagnano, Storia della filosofia. La filosofia antica, la Patristica e la Scolastica, Torino 2003, 539-540. So while philosophers and theologians seek to guarantee the objectivity of things' knowledge by means of epistemic theories drawn upon the plato-aristotelian tradition (i.e. illuminatio or the intellectus agens theory), Basil seems to have got rid of both. In doing this he is constraint to tolerate, or even to accept, some portion of probabilism as far as the knowledge of the created things concerned, although this fact doesn't seem to bother him at all. (It is of course a quite different issue the charismatic knowledge of God).

${ }^{22}$ Cf. Copleston, A History of Philosophy, p. 79-81. 
order to provide support to different theological purposes. Eunomius' rationalistic doctrine of God's knowledge, which goes hand in hand with his account of human language and mind, prompted Saint Basil to advance an empirical epistemological view that both makes possible a talk about God based on sense data and keeps fully intact the transcendence of God's essence.

\section{KONCEPCJA ŚW. BAZYLEGO Z CEZAREI I EUNOMIUSZA Z KYZIKU NA TEMAT EPINOIA: TŁO FILOZOFICZNO-TEOLOGICZNE}

\section{(Streszczenie)}

W artykule zwrócono uwagę na to, w jaki sposób, zarówno św. Bazyli, jak i jego przeciwnik - anomejczyk Eunomiusz z Kyziku, włączają w swą myśl teo-

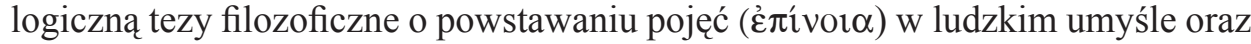
ich relacjach do zewnętrznych przedmiotów. W swych poszukiwaniach autor opracowania dostarcza dowodów na to, że teologowie ci przestudiowali ten sam materiał filozoficzny, dotyczący koncepcji ludzkiego umysłu; każdy z nich jednak zdecydował się użyć innych elementów zaczerpniętych z powiązanych tradycji filozoficznych w celu uwiarygodnienia różnych tez teologicznych. Racjonalistyczna doktryna Eunomiusza na temat Bożej wiedzy, która idzie w parze z jego koncepcją dotyczącą ludzkiego języka i umysłu, skłoniła św. Bazylego do rozwinięcia empirycznego poglądu epistemologicznego, który umożliwia zarówno mówienie o Bogu oparte na danych zmysłowych, jak i zachowuje w pełni nienaruszoną transcendencję Boskiej istoty.

Key words: epinoia, philosophy, theology, Basilius of Caesarea, Eunomius of Cysicus.

Słowa kluczowe: epinoia, filozofia, teologia, Bazyli z Cezarei, Eunomiusz z Kyziku.

\section{BIBLIOGRAPHY}

\section{Sources}

Augustinus, De magistro, ed. K.-D. Dauer, CCL 29, Turnhout 1970, 157-203.

Basilius Caesariensis, Adversus Eunomium, ed. B. Sesboüé- G.M. de Durand - L. Doutreleau, SCh 299, Paris 1982.

Basilius Caesariensis, De Spiritu Sancto, ed. B. Pruche, SCh 17b, Paris 2002.

Basilius Caesariensis, Epistulae, ed. Y. Courtonne: Saint Basile, Lettres, III, Paris 1966.

Basilius CAesariensis, Homilia in sanctum martyrem Mamantem, PG 31, 589-600.

Chalcidius, Commentarius in Timaeum, ed. J.H. Waszink, London 1962.

Cicero, De officiis, ed. W. Miller, London 1913.

Diogenes Laertius, Vitae philosophorum, ed. H.S. Long, t. 1-2, Oxford 1964.

Plato, Theaetetus, ed. H.N. Fowler, Cambridge (MA) - London 1961.

Sextus EmpIricus, Adversus mathematicos VII-VIII, ed. R.G. Bury, Cambridge (MA) 1997. 


\section{Literature}

Abbagnano N., Storia della filosofia. La filosofia antica, la Patristica e la Scolastica, Torino 2003.

ABramowski L., Eunomios, RACh VI 936-947.

Ayres L., Nicaea and his Legacy. An Approach to Fourth-Century Trinitarian Theology, Oxford 2006.

Barnes J., The Presocratic Philosophers, London - New York 2006.

Copleston F., A History of Philosophy. British Philosophy: Hobbes to Hume, London - New York 2003.

CROUzel H., Origen et le probléme de la “connaissance mystique”, Paris 1961.

Dams Th., La controverse eunomiéenne, Thèse polycopiée de la Faculté de Théologie de l'Institut Catholique de Paris 1952.

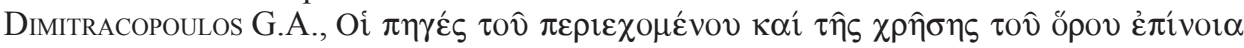

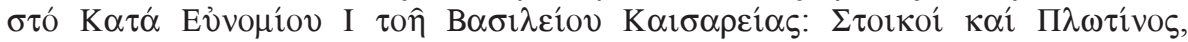

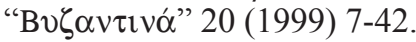

Drecoll V.H., Die Entwicklung der Trinitätslehre des Basilius von Cäsarea. Sein Weg vom Homöusianer zum Neonizäner, Göttingen 1996.

Hanson R.P.C., The Search for the Christian Doctrine of God. The Arian Controversy 318-381, Grand Rapids (MI) 2007.

Harl M., Origène et la fonction révélatrice du Verbe incarné, Patristica Sorbonensia 2, Paris 1958.

Hirschberger J., Geschichte der Philosophie, vol. 1: Altertum und Mittelalter, Freiburg - Basel - Wien 1991.

Kelly J.N.D., Early Christian Doctrines, New York 1960.

Kopecek Th.A., A History of Neo-Arianism, Patristic Monograph Series of the North American Patristic Society 8, vol. 2, Cambridge (MA) 1979.

Long A. - Sedley D., The Hellenistic Philosophers, vol. 2: Greek and Latin texts with notes and bibliography, Cambridge 1987.

Marenbon J., Medieval Philosophy. An historical and philosophical introduction, London - New York 2007.

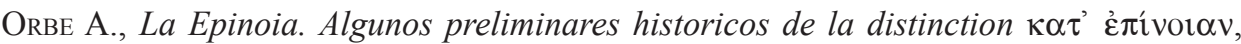
Romae 1955.

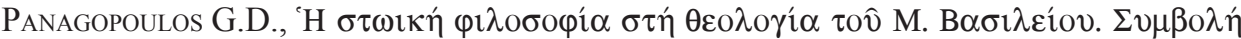

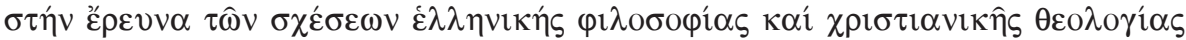

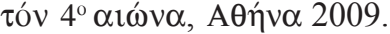

Pasnau R., Human Nature, in: A.S. McGrade, A Cambridge Companion to Medieval Philosophy, Cambridge 2003, 208-230.

Rius-Camps J., El Dinamismo trinitario en la divinization de los seres racionales segun Origenes, OCA 188, Roma 1970.

SesboüÉ B., Saint Basile et la Trinité. Un acte théologique au IVe siècle, Paris 1998.

Simonetti M., La crisi ariana nel IV secolo, Roma 1975.

Trigg J.W., Origen, London - New York 2002.

Troiano M.S., I Cappadoci e la questione dell'origine dei nomi nella polemica contro Eunomio, VetCh 17 (1980) 313-346.

Uthemann K.-H., Die Sprache der Theologie nach Eunomius von Cyzicus, ZKG 104 (1993) 143-175.

VagGione R.P., Eunomius of Cyzicus and the Nicene Revolution, Oxford 2000. 